Praxis : Jurnal Sains, Teknologi, Masyarakat dan Jejaring | Vol. 4 | No. 1 | September 2021

\title{
Menciptakan Kepuasan Pelanggan dan Minat Beli Ulang: Studi Empiris Pada Bisnis Wisata Kuliner Kreatif
}

\author{
Siti Zulaikha Wulandari' ${ }^{1}$ Hanisa Lail Shafirayana²; Sri Murni Setyawati ${ }^{3}$ \\ Universitas Jenderal Soedirman \\ email: siti.wulandari@unsoed.ac.id ${ }^{1}$; hanisashafira08@gmail.com ${ }^{2}$; \\ nunk_pwt@yahoo.co.id ${ }^{3}$
}

\begin{abstract}
Abstrak
Bisnis wisata kuliner kreatif memberikan peluang yang sangat potensial bagi para pelaku usaha. Persaingan antar bisnis kreatif kuliner saat ini semakin kompetitif sehingga perlu dipahami mengenai berbagai variabel yang berpengaruh terhadap kepuasan pelanggan dan minat beli ulang. Penelitian ini dilakukan untuk mengetahui pengaruh dari beberapa variabel yang dipersepsikan dapat mempengaruhi kepuasan pelanggan yang selanjutnya berpengaruh terhadap niat beli ulang dalam sebuah bisnis wisata kuliner kreatif. Secara khusus, model dalam penelitian ini dikembangkan untuk menguji pengaruh variabel kualitas produk, kualitas pelayanan, harga, dan servicescape terhadap kepuasan pelanggan dan pengaruhnya terhadap minat beli ulang. Berdasarkan analisis regresi berganda yang digunakan dalam menguji jawaban dari 107 responden yang dipilih dengan metode purposive sampling, diperoleh hasil yang menunjukkan signifikansi pengaruh variabel kualitas produk, kualitas pelayanan dan servicescape terhadap kepuasan pelanggan. Sebaliknya, variabel harga tidak memberikan pengaruh yang signifikan terhadap kepuasan pelanggan. Hasil penelitian juga menunjukkan adanaya pengaruh signifikan kepuasan pelanggan terhadap minat beli ulang. Pembahasan secara mendalam mengenai hasil temuan dari pengujian model penelitian ini didiskusikan dalam sub bab hasil penelitian.
\end{abstract}

Kata Kunci : kualitas produk, kualitas pelayanan, harga, servicescape, kepuasan pelanggan.

\begin{abstract}
The culinary tourism business provides a very potential opportunity for businessman. Competition among creative culinary businesses is currently getting more fierce, so it is important for the business to understand the variables that affect customer satisfaction and repurchase intention. This research was conducted to see the influence of several variables that are perceived affecting repurchase intention that mediated by customer satisfaction in a creative culinary tourism business. In particular, the model in this study was developed to test the effect of product quality, service quality, price, and servicescape on customer satisfaction that consequently influence repurchase intention. Multiple regression analysis were applied to analyse the answer of 107 respondents selected using purposive sampling method. The research results were obtained and showed the significant influence of product quality, service quality and servicescape on customer satisfaction. Whereas the price did not show a significant effect. In turn customer satisfaction significantly influence customer repurchase intention. In-depth discussion of the research finding was discussed in the section of results and discussion.
\end{abstract}

Keywords: product quality, service quality, price, servicescape, customer satisfaction. 
Praxis : Jurnal Sains, Teknologi, Masyarakat dan Jejaring | Vol. 4 | No. 1 | September 2021

\section{PENDAHULUAN}

Makanan atau kuliner merupakan komoditi penting yang merupakan bagian dari warisan budaya dan sosial. Rantai nilai pada proses produksi bisnis wisata kuliner lintas sektor memiliki dampak yang kuat terhadap pengembangan potensi daerah (The European Economic and Social Committee of European Union, 2012). Wisata kuliner dapat bersinergi lintas sektor dengan pertanian, kerajinan, pariwisata, dan sebagainya. Penciptaan inovasi dan pengetahuan terkait rantai nilai pada kuliner lintas sekor menjadi hal yang penting bagi seluruh pemangku kepentingan yang terus mencari terobosan pada peluang bisnis baru (Cavicchi dan Stancova, 2016).

Meskipun makanan telah lama dikaitkan dengan perjalanan dan rekreasi, wisata kuliner sebagai bagian dari ekonomi kreatif baru mendapat perhatian dalam beberapa tahun terakhir (Lin dan Baum, 2016). Saat ini, wisata kuliner menjadi salah satu sektor penting yang dapat berkontribusi signifikan pada perkembangan ekonomi masyarakat (Lee, 2012). Pengembangan wisata kuliner terjadi dengan mengangkat potensi lokal yang disajikan dengan menyesuaikan selera pangsa pasar yang menjadi target marketnya. Bisnis wisata kuliner dan gastronomy secara perlahan menempati posisi yang penting. Wisata kuliner dan gastronomy merupakan ekspresi budaya dan pilar fundamental dari hubungan sosial dan keluarga (Cavicchi dan Stancova, 2016). Inovasi dan kreasi lintas sektor memunculkan kuliner kreatif yang menjadi pendukung sektor pariwisata, sehingga dikenal istilah Culinary tourism atau wisata kuliner. Keberadaan wisata kuliner yang kreatif akan menjadi salah satu pendukung penting bagi industri pariwisata karena dapat membentuk place branding.

Bisnis wisata kuliner kreatif seringkali dikaitkan dengan gastronomi yang biasanya dimaknai sebagai seni menyiapkan hidangan yang lezat. Dalam gastronomi, pebisnis menawarkan sesuatu yang berbeda yang mengacu pada pengalaman makan dimana pebisnis benarbenar memperhatikan segala aspek mulai dari tekstur makanan, penyajian, sampai dengan rasa saat makanan disantap (https://www.cnnindonesia.com). Hal ini sejalan dengan dunia kuliner yang makin berkembang sangat pesat, dimana perilaku konsumen dalam menyantap makanan tidak lagi hanya mempertimbangkan soal rasa. Konsumen tidak lagi berkunjung ke sebuah restoran hanya bertujuan untuk sekedar makan, melainkan mencari sebuah pengalaman yang unik dan berbeda. Dalam kaitannya dengan pariwisata,

Kuliner kreatif berfokus pada produksi hidangan dengan ide baru yang dapat menyajikan makanan yang lebih baik dan lebih enak. Sifat kreativitas kuliner adalah hasil interaksi antara kreator (chef), organisasi dan pelanggan yang menciptakan tren fashion makanan guna memenuhi permintaan pasar sekaligus menghasilkan keuntungan (Peng, Lin dan Baum, 2013). Dari aspek eksternal, kreativitas kuliner para pelaku bisnis kuliner kreatif harus memahami perbedaan sifat kreativitas kuliner dengan bentuk kreativitas seni lain yang dapat dinikmati selama masa bertahun-tahun, seperti lukisan maupun karya seni lain. Kreativitas kuliner seringkali memeiliki keterbatasan waktu karena perubahan selera konsumen yang sangat cepat.

Meskipun pada dasarnya memiliki tujuan yang sama yaitu mengatasi rasa lapar dan memberi nutrisi, namun bisnis kuliner kreatif memerlukan berbagai strategi untuk bertahan dalam persaingan industri yang serupa (Peng, Lin dan Baum, 2013). Persaingan bisnis wisata kuliner yang ketat kini memicu pelaku bisnis kuliner untuk terus menerus melakukan pembaharuan dengan tujuan meningkatkan dan sekalligus mempertahankan pelanggannya. 
Praxis : Jurnal Sains, Teknologi, Masyarakat dan Jejaring | Vol. 4 | No. 1 | September 2021

Oleh Karena itu pelaku bisnis wisata kuliner perlu memahami dan memperhatikan apa yang melandasi konsumen dalam memilih suatu produk, serta apa yang dapat memberikan pengalaman wisata kuliner yang memuaskan sehingga konsumen bersedia melakukan pembelian ulang.

Berbagai studi membuktikan bahwa minat beli ulang dipengaruhi oleh kepuasan pelanggan. Hal tersebut berlaku pula dalam bisnis wisata kuliner kreatif. Sejumlah peneliti seperti Lee, Park, dan Cho (2011) membuktikan pengaruh kepuasan pelanggan terhadap minat beli ulang pada konsumen produk kuliner instan, dimana kepuasan tersebut dipengaruhi oleh values, kemanfaatan, pilihan menu, kenyamanan dan kualitas makanan. Demikian pula kajian Suchánek, Richter dan Králová (2017) memberikan hasil serupa yang menunjukkan bahwa kepuasan pelanggan dan minat membeli ulang saling berkaitan.

Kepuasan pelanggan menjadi faktor penting yang dapat menentukan keberlangsungan sebuah bisnis. Hasil kajian Arsyanti dan Astuti (2016) membuktikan bahwa mutu produk, mutu layanan, dan fitur produk memiliki dampak positif pada kepuasan pelanggan dan selanjutnya berdampak pada minat beli ulang. Secara lebih spesifik, kajian lain menjelaskan bahwa kepuasan pelanggan kuliner juga ditentukan oleh harga dan physical environment (Hanaysha, 2016). Hasil studi Sabir, dkk (2014) membuktikan adanya beberpa faktor yang mempengaruhi kepuasan pelanggan dalam bisnis kuliner, yaitu kualitas produk, harga, desain fisik dan layanan.

Mengacu pada beberapa hasil penelitian terdahulu dan kajian empiris yang ada, maka penelitian ini bermaksud menguji model penciptaan kepuasan pelanggan dan minat beli ulang konsumen kuliner kreatif. Penelitian ini dilakukan pada sebuah usaha kuliner kreatif berupa cafe Gelato yang ada di Yogyakarta. Sebagai salah satu kota tujuan wisata utama di Indonesia, Yogyakarta dikenal dengan berbagai produk kreatif termasuk kuliner kreatif yang saat ini terus bermunculan, baik yang murni mengangkat potensi lokal maupun mengkombinasikannya dengan selera global dan kekinian.

Saat ini banyak pebisnis membuka wisata kuliner kreatif berupa restoran dengan konsep café yang dipersepsikan affordable atau dapat dijangkau oleh semua elemen masyarakat. Dengan banyaknya jumlah café yang terus bermunculan, maka pelaku bisnis kuliner harus memastikan bahwa produk dan jasa layanannya dapat memuaskan konsumen, dengan memastikan bahwa harapan konsumen ketika memasuki restoran dapat dipenuhi dengan baik. Dalam penelitian ini akan diuji pengaruh variabel - variabel yang dipersepsikan menentukan kepuasan konsumen dan minat beli ulang pada konsumen wisata kuliner kreatif, yang meliputi varibel Mutu Produk, Mutu Layanan, Serviecescape dan Harga.

\section{TELAAH LITERATUR DAN PENGEMBANGAN HIPOTESIS}

\section{Wisata Kuliner Kreatif}

Tidak terdapat definisi tunggal yang diterima secara umum mengenai pengertian wisata kuliner kreatif. Beberapa definsi yang ada, umunya menjelaskan secara terpisah beberapa pemahaman istilah yang terkait dengan wisata kuliner kreatif, seperti: Gastronomi, wisata kuliner (culinary tourism) atau wisata makanan (food tourism), wisata kreatif dan kuliner kreatif. Menurut Horng (2012), culinary tourism pertama kali dikenal pada tahun 1998, yang mengacu pada sebuah konsep dimana wisatawan dapat mengalami budaya yang berbeda dengan cara 
Praxis : Jurnal Sains, Teknologi, Masyarakat dan Jejaring | Vol. 4 | No. 1 | September 2021

menikmati makanan yang disajikan pada buadaya tersebut. Culinary tourism merupakan bentuk pariwisata yang secara signifikan menekankan hubungan antara orang dalam dan orang luar yang diciptakan melalui makanan sebagai sebuah budaya. Horng dan Tsai (2010) juga menjelaskan bahwa wisata kulinaer merupakan pengalaman melalui aktivitas yang berhubungan dengan makanan yang didalamnya terdapat pembelajaran budaya dan transfer pengetahuan tentang destinasi wisata dan masyarakatnya. Makanan dalam wisata kuliner dipandang sebagai media pengalaman budaya.

Menurut Elis, dkk (2018), Hall dan Sharples merupakan peneliti awal yang banyak menjadi rujukan bagi kajian dalam bidang Food tourism, dan memberikan definisi food tourism sebagai kunjungan ke produsen makanan, festival makanan, restoran, dan lokasi tertentu yang didorong oleh keinginan atau tujuan untuk mencicipi atau menikmati makanan/minuman dan atau mendapatkan atribut pengalaman dari tempat produksi makanan tersebut secara khusus. Berbagai definisi di atas menekankan adanya unsur pengalaman wisatawan tentang makanan lokal, dan bukan hanya wisatawan yang ingin menikmati makanan semata sekedar

Selanjutnya untuk memahami wisata kuliner kreatif maka perlu pemahaman mengenai kuliner kreatif. Istilah ini sangat relevan dengan inovasi dan kreativitas. Saat ini pariwisata sangat berpengaruh terhadap perkembangan industri kreatif, dan sebaliknya industri kreatif yang berkembang akan menjadikan suatu daerah menjadi tujuan wisata yang unggul (Muizu, 2016). Dengan demikian, kuliner kreatif sebagai bagian dari industri kreatif dapat memunculkan wisata kuliner kreatif. Dalam konteks manajemen, kreatifitas adalah pengembangan ide-ide baru pada produk, jasa layanan atau prosedur yang secara potensial memberikan manfaat bagi organisasi (Horng dan $\mathrm{Hu}, 2009$ ). Oleh karena itu, kuliner kreatif merupakan kuliner yang terus mengalami inovasi dan pengembangan baik produknya, jasa layanannya maupun proses atau prosedur pembuatannya.

\section{Kualitas Produk}

Sebuah produk harus memiliki kuallitas yang sesuai dengan harapan dan kebutuhan konsumen. Kotler dan Keller (2009) menjelaskan bahwa kualitas adalah totalitas fitur dan karakteristik produk atau jasa yang bergantung pada kemampuan untuk memuaskan kebutuhan yang dinyatakan atau tersirat. Secara lebih khusus, Kotler dan Amstrong (2012) mendefinsikan kualitas produk sebagai kemampuan suatu produk dalam memeragakan fungsinya, termasuk keseluruhan durabilitas, reliabilitas, ketepatan, kemudahan pengoperasian dan resparasi produk juga atribut produk lainnya.

Menurut Lee, Park dan Cho (2011), Jefry dkk (2014), dan Razak (2016), kualitas produk berpengaruh signifikan terhadap kepuasan pelanggan. Hal yang sama juga dibuktikan oleh Ransulangi dkk (2015) yang menjelaskan bahwa kualitas produk berpengaruh positif terhadap kepuasan konsumen.

\section{H1: Kualitas Produk berpengaruh positif terhadap Kepuasan Pelanggan.}

\section{Kualitas Pelayanan}

Kualitas pelayanan merupakan upaya pemenuhan kebutuhan dan keinginan konsumen serta ketepatan penyampaiannya dalam mengimbangi harapan konsumen (Tjiptono, 2014). Menurut Ubaidillah dan Soekotjo (2017) kualitas pelayanan adalah suatu kegiatan yang memberikan manfaat dan kepuasan yang akan ditawarkan kepada konsumen. Layanan dianggap sebagai pertukaran tindakan, pengetahuan, kesadaran, sikap, perilaku, aktivitas, budaya, epuasan konsumen, nilai, 
Praxis : Jurnal Sains, Teknologi, Masyarakat dan Jejaring | Vol. 4 | No. 1 | September 2021

kesejahteraan antar layanan penyedia dan pelanggan. Benda tak berwujud ini sama pentingnya bagi penyedia yang memiliki inti model bisnis yang dirancang untuk produk. Pemikiran yang berfokus pada produk dan manufaktur tidak akan mampu mengembangkan keunggulan kompetitif yang berkelanjutan. Sedangkan pemikiran dan perilaku berorientasi kualitas layanan diperlukan untuk menjadi tujuan strategis perusahaan dan membantu perusahaan untuk melayani pelanggan mereka dengan perilaku interpersonal dan teknis yang lebih dekat yang selanjutnya menghasilkan kepuasan dan loyalitas pelanggan. Baik tidaknya kualitas layanan tergantung pada kemampuan penyedia jasa untuk memenuhi harapan pelanggan secara konsisten. Sehingga dapat disimpulkan bahwa kualitas pelayanan adalah kemampuan perusahaan dalam melayani konsumen secara tepat yang mendorong terciptanya kepuasan pelanggan.

Ferninda (2013), Nadia dkk (2013) serta Mensah dan Mensah (2018) menyatakan bahwa kualitas pelayanan berpengaruh postif dan signifikan terhadap kepuasan konsumen. Berdasarkan hal tersebut, maka dikembangkan hipotesis sebagai berikut:

\section{H2: Kualitas Pelayanan Berpengaruh Positif terhadap Kepuasan Pelanggan}

\section{Harga}

Harga adalah sejumlah uang yang dibebankan atas suatu produk atau jasa, atau jumlah dari nilai yang ditukar konsumen atas kegunaan karena memiliki atau menggunakan produk atau jasa tersebut (Kotler dan Amstrong, 2008). Harga sering kali menjadi indikator utama kualitas sebuah produk atau jasa, dengan kata lain pelanggan mempunyai harapan yang sesuai dengan jumlah uang yang telah mereka korbankan. Oleh karena itu, perusahaan harus menentukan strategi harga dengan tepat untuk dapat sukses dalam memasarkan barang atau jasa dan agar dapat menciptakan kepuasan konsumen.

Penelitian yang dilakukan oleh Sabir (2014), Ransulangi, dkk (2015) dan Razak (2016), membuktikan bahwa price (harga) berpengaruh signifikan terhadap kepuasan pelanggan. Oleh karena itu dalam penelitian ini diajukan hipotesis sebagai berikut:

\section{H3: Harga berpengaruh positif terhadap Kepuasan Pelanggan}

\section{Servicespace}

Lingkungan fisik sebuah bisnis kuliner kreatif dapat membangun sebuah keunggulan kompetitif. Service scape merupakan kesan-kesan yang diciptakan pada pancaindera oleh perancangan lingkungan fisik tempat jasa diserahkan (Lovelock dan Wirtz, 2011). Definisi servicescape telah berkembang dalam rentang waktu yang cukup lama, dan telah mengalami berbagai kritik dan pengembangan. Rosenbaum dan Massiah (2011) mengembangkan pemahaman mengenai servicescape yang sebelumnya di kemukakan oleh Zeithaml, dkk. Servicescape merupakan linkungan dimana sebuah jasa layanan diberikan secara interaktif kepada konsumen melalui komoditas berwujud dan atau komunikasi, yang mencakup beberapa dimensi, seperti dimensi fisik, sosial, simbolis sosial, dan alamiah. Servicescape akan mempengaruhi psikologi pelanggan dan menciptakan emosional. Berdasarkan Penjelasan di atas, dapat dikatakan bahwa servicescape adalah kondisi lingkungan fisik yang mendukung proses pelayanan, yang dirancang semenarik mungkin untuk menarik konsumen.

Menurut penelitian yang dilakukan oleh Manoppo (2013), Sabir (2014), Ransulangi dkk (2015), serta Meika dan Rini (2015) membuktikan bahwa servicescape berpengaruh signifikan terhadap kepuasan 
Praxis : Jurnal Sains, Teknologi, Masyarakat dan Jejaring | Vol. 4 | No. 1 | September 2021

pelanggan. Oleh karena itu dikembangkan hipotesis sebagai berikut:

\section{H4: Servicescape berpengaruh positif terhadap Kepuasan Pelanggan}

\section{Kepuasan Pelanggan dan Minat Beli Ulang}

Kepuasan konsumen merupakan prioritas utama bagi setiap perusahaan. Kepuasan pelanggan dapat didefinisikan dengan menggunakan dua konsep dasar, yaitu: kepuasan berbasis transaksi dan kepuasan kumulatif. Kepuasan berbasis transaksi didasarkan pada evaluasi pembelian tertentu setelah pemilihan dibuat dan produknya telah dibeli. Di sisi lain, kepuasan kumulatif didasarkan pada keseluruhan pengalaman setelah pembelian dan penggunaan produk/ layanan selama jangka waktu tertentu (Suchánek, Richter dan Maria Králová, 2017). Kepuasan adalah konsep yang jauh lebih luas dari hanya sekedar penilaian kualitas pelayanan, namun juga dipengaruhi oleh faktor-faktor lain seperti: Kualitas pelayanan atau jasa, Kualitas produk, dan Harga.

Kepuasan pelanggan diketahui dapat menciptakan minat beli ulang. Hal ini selaras dengan pendapat yang mendefiniskan minat beli ulang sebagai sebuah niatan untuk melakukan tindakan konsumsi sebuah produk dengan merk tertentu secara berulang (lebih dari sekali) karena konsumen puas dengan layanan yang diberikan (Peter dan Olson, 2010). Hasan (2013) mendefinisikan Minat Beli Ulang sebagai sebuah niat yang dikaitkan dengan perilaku masa lalu yang secara langsung mempengaruhi niat untuk kembali melakukan konsumsi sebuah produk tertentu di masa yang akan datang. Dari beberapa pendapat di atas, dapat disimpulkan bahwa minat pembelian ulang merupakan keputusan konsumen untuk terlibat dalam kegiatan dengan penyedia layanan dan bentuk kegiatan semacam itu di masa depan yang terjadi setelah konsumen membeli dan menggunakan produk yang ditawarkan oleh produsen sebagai akibat dari evaluasi penggunaan produk atau jasa tertentu.

Kepuasan pelanggan memberi dampak terhadap minat beli ulang, hal ini dapat diartikan bahwa apabila konsumen merasa puas dan bahagia dengan pelayanan yang baik, kualitas makanan yang baik, dan suasana restoran yang nyaman maka konsumen merasakan kepuasan lalu berniat mengunjungi kembali.

Hasil kajian terdahulu dari Lee, Park dan Cho (2011) yang melakukan penelitian pada bisnis kuliner, Nuri dan Sri (2016), Mensah dan Mensah (2018) serta Ryu et al (2016) menyatakan bahwa kepuasan pelanggan berpengaruh positif terhadap minat berperilaku, khususnya adalah minat beli ulang. Mengacu pada penjelasan tersebut, maka dikembangkan hipotesis sebagai berikut:

\section{Hs: Kepuasan Pelanggan berpengaruh positif terhadap Minat Beli Ulang.}

\section{MODEL PENELITIAN}

Penelitian ini adalah penelitian survey yang menggunakan kuesioner sebagai instrument pengumpulan data. Penelitian ini dilaksanakan di sebuah Cafe wisata kuliner gelato di Yogyakarta. Populasi penelitian adalah seluruh konsumen yang pernah mengunjungi cafe tersebut. Berdasarkan perhitungan sampel minimal dan perkiraan repsons rate, maka jumlah kuesioner yang disebarkan adalah 196 eksemplar. Analisis data dilakukan terhadap 107 kuesioner yang kembali dan terisi dengan lengkap. Penelitian ini menggunakan purposive sampling berdasarkan kriteria usia (diatas 19 tahun). Untuk mengukur tanggapan responden digunakan skala likert lima tingkat, dengan skor 5 untuk jawaban Sangat Setuju (SS) 
Praxis : Jurnal Sains, Teknologi, Masyarakat dan Jejaring | Vol. 4 | No. 1 | September 2021

sampai dengan skor 1 untuk jawaban Sangat Tidak Setuju (STS). Untuk menguji hipotesis penelitian, dilakukan analisis data statistik regresi linier berganda dan regresi sederhana.

\section{HASIL PENELITIAN DAN PEMBAHASAN}

Perbedaan kondisi demografis individu dapat memberikan perbedaan sikap, harapan dan perilaku dalam keputusan pembelian maupun aktvitas konsumsi lainnya. Oleh Karena itu, penelitian ini menyajikan karakteristik responden berdasarkan demografi agar dapat lebih memahami pola perilaku konsumen yang

\section{Tabel 1}

\section{Karakteristik Responden Berdasarkan Gender, Usia, Pekerjaan dan Pendapatan}

\begin{tabular}{lrr}
\hline \multicolumn{1}{c}{ Karakter Demografis } & Jumlah (orang) & Persentase (\%) \\
\hline Gender (Jenis Kelamin) & & \\
- Laki-Laki & 27 & 25 \\
- Wanita & 80 & 75 \\
Rentang Usia & & \\
- 19 - 29 tahun & 105 & 98 \\
- > 29 tahun & 2 & 2 \\
Pekerjaan & & \\
- Pelajar/ Mahasiswa & 94 & 57 \\
- Pengusaha/Wiraswasta & 5 & 1 \\
- PNS/BUMN & 1 & 7 \\
- Swasta & 7 & \\
Penghasilan/Uang saku & & 2.8 \\
- - Rp 1.000.000 & 3 & 75.7 \\
- Rp 1.000.000 - Rp 3.000.000 & 81 & 19.7 \\
- Rp 3.000.000 - Rp 5.000.000 & 21 & 1.8 \\
- > Rp 5.000.000 & 2 & \\
\hline
\end{tabular}

Sumber : Data Diolah (2021)

Sebelum dilakukan analisis regresi, terlebih dahulu dilakukan uji asumsi klasik yang meliputi uji validitas, reliabilitas, normalitas, multikolinearitas dan heteroskesdastistas. Keseluruhan hasil uji asumsi klasik tersebut telah memenuhi persyaratan untuk dilakukannya analisis regresi dalam model penelitian. Berdasarkan output analisis regresi berganda dengan bantuan software SPSS for Windows dapat dibuat persamaan regresi berganda sebagai berikut: relevan. Berdasarkan Jenis kelamin, Usia, Pendapatan dan Pekerjaan, diketahui bahwa responden penelitian didominasi oleh konsumen perempuan, dengan rentang usia 19-29 tahun, pekerjaan pelajar atau mahasiswa dan Penghasilan atau uang saku mulai dari Rp 1.000.000 hingga Rp 3.000.000 perbulan.

Karakteristik tersebut relevan dengan obyek penelitian berupa Café Gelato, yang menjual sejenis minuman/makanan yang saat ini digemari oleh kalangan muda. Selain itu, Café gelato tersebut juga memiliki spot foto yang instragamable, sehingga menjadi salah satu tujuan wisata kuliner yang banyak diburu oleh millennial. 
Praxis : Jurnal Sains, Teknologi, Masyarakat dan Jejaring | Vol. 4 | No. 1 | September 2021

juga dilakukan, dengan melihat hasil Uji F, dimana hasil analisis menunjukkan nilai Fhitung sebesar 30,924 lebih besar dari nilai Ftabel dengan sebesar 2,45. Hasil uji $\mathrm{F}$ tersebut menunjukkan bukti bahwa model regresi berganda yang terbentuk dinyatakan tepat atau cocok dengan data hasil penelitian.

Pengujian signifikansi pengaruh kualitas produk, kualitas pelayanan, harga maupun variabel servicescape terhadap kepuasan pelanggan secara parsial dilakukan dengan menggunakan uji t. Hasil analisis regresi berganda menunjuukan bahwa nilai thitung variabel kualitas produk sebesar 3,493, nilai thitung variabel kualitas pelayanan sebesar 2,607, nilai thitung variabel harga sebesar 1,594 dan nilai thitung variabel servicescape sebesar 2,438. Hasil uji thitung pada variabel kualitas produk, kualitas pelayanan dan servicescape menunjukkan nilai yang lebih besar dibandingkan dengan nilai ttabel $(1,660)$. Sedangkan nilai thitung pada variabel harga menunjukkan nilai yang lebih kecil dibandingkan dengan nilai ttabel sebesar 1,660 . Dengan demikian maka dapat disimpulkan bahwa variabel kualitas produk, kualitas pelayanan dan servicescape berpengaruh signifikan terhadap kepuasan pelanggan, sedangkan variabel harga tidak berpengaruh signifikan.

Selanjutnya untuk menguji hipotesis kelima, dilakukan analisis regresi sederhana guna menguji pengaruh kepuasan pelanggan terhadap minat beli ulang, dan diperoleh hasil persamaan:

$\mathrm{Y} 2=2,805+0,242 \mathrm{Y} 1$

Hasil analisis regresi menunjukkan nilai koefisien determinasi (R2) sebesar 0,567, artinya sebesar 56,70 persen variasi perubahan variabel minat beli ulang dapat dijelaskan oleh perubahan variabel kepuasan pelanggan, sedangkan 43,30 persen dapat dijelaskan oleh variabel- variabel lain yang tidak diteliti. Uji Kelayakan Model Regresi menggunakan Uji $\mathrm{F}$ menunjukkan bahwa nilai Fhitung sebesar 137,490 lebih besar dari nilai Ftabel sebesar 3,92. Dengan demikian, dapat dinyatakan bahwa model regresi sederhana yang terbentuk adalah tepat atau cocok dengan data hasil penelitian (goodness of fit).

Pengujian signifikansi pengaruh variabel kepuasan pelanggan terhadap minat beli ulang dengan uji t memberikan nilai ttabel untuk pengujian satu sisi (one tailed) sebesar 1,660 dan nilai thitung variabel kepuasan pelanggan sebesar 11,726. Hal ini membuktikan bahwa pernyataan hipotesis kelima dalam penelitian ini yang menyatakan bahwa Kepuasan Pelanggan berpengaruh positif terhadap Minat Beli Ulang, diterima.

Secara statistik hasil penelitian ini membuktikan bahwa kualitas produk mempunyai pengaruh yang positif dan signifikan terhadap kepuasan pelanggan Cafe di Yogyakarta. Hubungan kausal tersebut menunjukkan bukti bahwa semakin baik persepsi konsumen terhadap kualitas produk yang ditawarkan, maka akan semakin tinggi pula tingkat kepuasan mereka.. Kualitas produk gelato di Café dinilai baik terutama pada indikator berupa tersedianya berbagai macam varian rasa yang dapat dipilih oleh konsumen.

Hasil penelitian ini juga membuktikan bahwa kualitas pelayanan mempunyai pengaruh yang positif dan signifikan terhadap kepuasan pelanggan Café di Yogyakarta. Kualitas pelayanan yang dipersepsikan baik oleh pelanggan antara lain adalah peralatan yang digunakan menarik dan karyawan sopan terhadap pelanggan.

Hasil yang berbeda ditunjukkan pada pengaruh harga terhadap kepuasan pelanggan yang tidak signifikan. Pelanggan mempersepsikan harga yang 
Praxis : Jurnal Sains, Teknologi, Masyarakat dan Jejaring | Vol. 4 | No. 1 | September 2021

dibayarkan sesuai dengan kualitas produk yang di dapatkan. Namun hal ini tidak berpengaruh terhadap kepuasan mereka. Dalam mengkonsumsi sebuah produk wisata kuliner kreatif, seringkali harga bukan merupakan pertimbangan utama bagi konsumen, karena tujuan wisata kuliner kreatif bukan semata untuk menikmati sajian makanan melainkan keseluruhan layanan dan lingkungan pada lokasi kuliner kreatf tersebut.

Hasil penelitian ini membuktikan bahwa servicescape mempunyai pengaruh yang positif dan signifikan terhadap kepuasan pelanggan Café di Yogyakarta. Salah satu indikator yang dinilai paling baik oleh responden adalah desain interior Café yang unik. Kondisi fisik lingkungan yang merupakan tempat untuk saling berinteraksi memiliki peranan yang sangat penting untuk memperkuat tingkat kepuasan konsumen. Hal ini dapat dilakukan dengan menata serta merancang ruangan semenarik mungkin dan memberikan kenyamanan terhadap pengunjung.

Selanjutnya, hasil penelitian ini juga membuktikan bahwa kepuasan pelanggan mempunyai pengaruh yang positif dan signifikan terhadap minat beli ulang responden Semakin tinggi tingkat kepuasan pelanggan, maka akan semakin kuat minat pelanggan untuk melakukan pembelian ulang. Data yang diperoleh menunjukkan bahwa kepuasan yang paling besar yang dirasakan oleh responden adalah kepuasan terhadap produk. Hasil penelitian ini sejalan dengan studi yang dilakukan oleh Nuri dan Sri (2016) yang juga membuktikan bahwa kepuasan pelanggan berpengaruh positif dan signifikan terhadap minat beli ulang.

\section{SIMPULAN}

Kualitas produk, kualitas pelayanan dan Servicescape berpengaruh positif terhadap kepuasan pelanggan sedangkan Harga tidak berpengaruh signifikan. Kepuasan pelanggan terbukti berpengaruh positif terhadap minat beli ulang pelanggan Café di Yogyakarta. Kesimpulan hasil penelitian tersebut memberikan Implikasi Manajerial bagi pemilik bisnis wisata kuliner kreatif Café gelato untuk memprioritaskan strategi yang terkait dengan kualitas produk, kualitas pelayanan, dan servicescape. Cara yang dapat dilakukan anatara lain dengan memberikan cita rasa produk yang khas, menggunakan bahan yang berkualitas, menjaga kebersihan dapur, dan melakukan quality kontrol pada saat mengolah produk. Dalam upaya menjaga kualitas layanan, maka karyawan yang memberikan pelayanan perlu selalu menjaga keramahan pada pelangganya khususnya pada saat suasana cafe tergolong ramai. Pembenahan pada lingkungan fisik dapat dilakukan dengan terus melakukan inovasi atau penyegaran desain dan interior, pengaturan cahaya penerangan dan suhu ruangan, memperluas area parkir, dan lebih menajamkan aroma gelato agar menjadi ciri khas dari sebuah Cafe Gelato.

Terkait keterbatasan penelitian adalah kemungkinan adanya bias data dalam yang diperoleh dari responden. Hal ini disebabkan sebagian pendistribusian kuesioner dilakukan secara tidak langsung (melalui google forms) sehingga tidak semua responden didampingi pada saat mengsisi kuesener. Kondisi tersebut memungkinkan terjadinya perspsi responden yang tidak sesuai dengan yang dimaksudkan oleh peneliti.

Dalam upaya untuk mengembangkan dan memperkaya kajian dalam ranah wisata kuliner kreatif, maka disarankan bagi penelitian selanjutnya untuk melakukan penelitian pada obyek yang lebih 
Praxis : Jurnal Sains, Teknologi, Masyarakat dan Jejaring | Vol. 4 | No. 1 | September 2021

berragam, memperluas cakupan penelitian agar hasil penelitian nantinya dapat lebih obyektif dan dapat digeneralisasikan. Wisata kuliner kreatif identik dengan potensi produk lokal dan proses pembuatan yang unik, sehingga konsumen mendapatkan pengalaman yang lebih berkesan dalam menikmati wisata kuliner kreatif tersebut. Oleh karena itu, perlu di lakukan penelitian pada obyek yang memiliki karakteristik tersbut. Penelitian selanjutnya juga dapat diarahkan pada pengembangan model dengan menambahkan variabel pemediasi misalnya persepsi nilai (perceived value), atau menambah kan variabel pemoderasi, misalnya promosi dan word of mouth (WOM).

\section{DAFTAR PUSTAKA}

Arsyanti , Nuri Mahdi dan Sri Rahayu Tri Astuti. (2016). Analisis Pengaruh Kualitas Produk, Kualitas Layanan dan Keberagaman Produk Terhadap Kepuasan Pelanggan Serta Dampaknya Terhadap Minat Beli Ulang. Diponegoro Journal Of Management. Vol. 5.No 2, hal. 1-11.

Cavicchi, Alessio dan Katerina Ciampi Stancova. 2016. Food and Gastronomy as Elements of Regional Innovation Strategies, JRC Science Hub ISBN 978-92-79-56682-0 ISSN 1831-9424

Ellis, Ashleigh, Eerang Park, Sangkyun Kimc dan Ian Yeoman. (2018). What is food tourism? Tourism Management 68 (2018) 250-263

European Commission. (2012). The Common Agricultural Policy - A Story To Be Continued. Luxembourg: Publications Office of the European Union.

Hanaysha, Jalal. (2016). Testing The Effects of Food Quality, Price Fairness, and Physical Environment on Customer Satisfaction in Fast Food
Restaurant Industry, Journal of Asian Business Strategy, 6(2)2016: 31-40

Hasan, A. (2013). Marketing Dan Kasus Kasus Pilihan. Yogyakarta: CAPS (Center For Academic Publishing Service).

Horng, Jeou-Shyan dan Meng-Lei Hu. (2009). The Impact of Creative Culinary Curriculum on Creative Culinary Process and Performance, Journal of Hospitality, Leisure, Sport and Tourism Education, 8 (2), 34 - 46

Horng Jeou-Shyan and Chen-Tsang (Simon) Tsai. (2012) Exploring Marketing Strategies for Culinary Tourism in Hong Kong and Singapore, Asia Pacific Journal of Tourism Research, 17:3, 277-300

Hwang, Jinsoo dan Jinlin Zhao. (2010). Factors Influencing Customer Satisfaction or Dissatisfaction in the Restaurant Business Using Answer Tree Methodology, Journal of Quality Assurance in Hospitality \& Tourism, Volume 11, Issue 2 April 2010, pages $93-110$.

Jefry F.T Bailia dkk. (2014). Pengaruh Kualitas Produk, Harga, dan Lokasi Terhadap Kepuasan Konsumen pada Warung Makan Lamongan di Kota Manado. Jurnal Emba: Vol. 2.No. 3, hal. 1768-1780.

Kisang Ryu, Hye-Rin Lee, and Woo Gon Kim. (2016). The Influence of The Quality of The Physical Environment, Food, and Service on Restaurant Image, Customer Perceived Value, Customer Satisfaction, and Behavioral Intentions. International Journal of Contemporary

Management Vol. 24 No. 2 59-68.

Kotler, Philip., dan Armstrong, Gary. (2008). Prinsip-prinsip Pemasaran. Edisi 12. Penerbit Erlangga, Jakarta. (2012). Principles Of Marketing. New Jersey : Pearson Education Limited.

Kotler, P., Keller, K.L. (2009). Manajemen Pemasaran. Jilid 1,2. Edisi 12. PT Indeks : Jakarta. 
Praxis : Jurnal Sains, Teknologi, Masyarakat dan Jejaring | Vol. 4 | No. 1 | September 2021

Lee, Bo-Soon, Park, Ki-Hong dan Cho, Jong-Hwan. (2011). A Study on The Effect of Selection Attributes on Consumer Satisfaction and Repurchase intention about HMR - In Case of Ready-to-end-cook, Culinary Science and Hospitality Research, Volume 17 Issue 2 / Pages.85-97 / 2011 / 2466-0752(pISSN) / 24661023(eISSN)

Lee, Anne H.J. (2012). The Creative Food Economy and Culinary Tourism through Place Branding: 'TERROIR' Into a Creative and Environmentally Friendly Taste of a Place, Doctoral Thesis, University of Waterloo, Ontario, Canada.

Lin, P. M. C., \& Baum, T. (2016). The meaning of applied creativity in the culinary industry. International Journal of Hospitality and Tourism Administration, 17(4), 429-448. DOI: 10.1080/15256480.2016.1226153

Lovelock, Christoper., Jochen Wirtz., Jacky Mussry. (2011). Pemasaran Jasa Manusia, Teknologi, dan Strategi Perspektif Indonesia. Jilid 2. Edisi ketujuh. Erlangga : Jakarta.

Manoppo, Ferninda. 2013. Kualitas Pelayanan, dan Servicescape Pengaruhnya Terhadap Kepuasan Konsumen pada Hotel Gran Puri Manado. Jurnal Emba. Vol. 1.No.4, hal. 1341-1348.

Mega Silvia Ransulangi dkk. (2015). Pengaruh Kualitas Produk, Harga Dan Servicescape Terhadap Kepuasan Konsumen Pengguna Rumah Makan Ocean 27 Manado. Jurnal Emba: Vol. 3.No. 3, hal. 839-848.

Meika, Putra Pratama dan Setyo Rini. (2015). Pengaruh Servicescape terhadap Kepuasan Konsumen Kafe Roti Gempol dan Kopi Anjis Cabang Jalan Bengawan Bandung. eProceeding of Management. Vol. 2. No.1, hal 749-757

Mensah, Ishmael dan Rebecca Dei Mensah. (2018). Effects of Service
Quality and Customer Satisfaction on Repurchase Intention in Restaurants on University of Cape Coast campus. Journal of Tourism, Heritage \& Services Marketing, Vol. 4, No. 1, pp. 27-36, 2018

Muizu, Wa Ode Zusnita. (2016). Competency Development of Culinary Creative Industries, Academy of Strategic Management Journal Volume 15, Special Issue 3

Nadia Rizqiyatul Faizah dkk. (2013). Pengaruh Harga, Kualitas Produk dan Kualitas Pelayanan Terhadap Kepuasan Pelanggan Restoran OMamamia Steak and Ice Cream Cabang Jati Semarang. e-journal Undip, hal 1-8.

Peng, KL., Lin, MC. dan Baum, T. (2013). The Constructing Model of Culinary Creativity: An Approach of Mixed Methods. Qual Quant 47, 2687-2707 https://doi.org/10.1007/s11135-0129680-9

Peter, J. P., \& Olson, J. C. (2010). Consumer Behavior \& Marketing Strategy. New York: McGraw-Hill Irwin.

Petr Suchánek, Jiř́ Richter dan Maria Králová. (2017). Prague Economic Papers, 2017, vol. 2017, issue 1, 19-35

Razak, Ismail. (2016). The Impact of Product Quality and Price on Customer Satisfaction With The Mediator Of Customer Value. Journal Of Marketing and Consumer Research. Vol. 30, hal.

Rosenbaum, M.S, dan Massiah, C. (2011), An expanded servicescape perspective. Journal of Service Management, Vol. 22, no 4, pp. 471490

Sabir, Raja Irfan, Muhammad Irfan, Naeem Akhtar, Muhammad Abbas Pervez, Asad ur Rehman. (2014). Customer Satisfaction in The Restaurant Industry; Examining the Model in Local Industry Perspective, Journal of Asian Business Strategy, 4(1)2014: 18-31 
Praxis : Jurnal Sains, Teknologi, Masyarakat dan Jejaring | Vol. 4 | No. 1 | September 2021

Tjiptono, Fandy. (2014). Pemasaran Jasa -

Prinsip, Penerapan, dan Penelitian.

Edisi I. Andi :Yogyakarta.

Ubaidillah Al Ahror dan Hendri Soekotjo.

(2017). Pengaruh Kualitas Pelayanan,

Harga Dan Lokasi Terhadap Kepuasan

Pelanggan Cafe Milkmoo. Jurnal Ilmu dan Riset Manajemen. Vol 6. No.3, hal Vol. 2. No.1, hal 749-757.

https://www.cnnindonesia.com/gaya-

hidup/20180305180404-262-

280650/gastronomi-pengalaman-

berbeda-menyantap-kuliner diakses 10

Feb 2021 